\title{
Gastronomy Traditional Culinary "Lemang" on Tanjung Sirih - Lahat District
}

\author{
Arief Marna Sonjaya ${ }^{1}$, Melati Pratama ${ }^{2 *}$, Trisna Rahmania ${ }^{3}$ \\ ${ }^{1,2,3}$ Palembang Polytechnic Tourism \\ *Corresponding author.email: melatipratama07002@gmail.com
}

\begin{abstract}
Lemang was one of Lahat traditional culinary. Lemang had a delicious taste like umami taste and sweet taste, and had unique performance like cooked and packed in bamboo. In fruit season arrived, lemang had various taste that be identifier of area, like lemang durian. The others variant of lemang in Lahat was mixed fish from Lematang river. Lemang not only culinary, but also contained history, culture, geography and cooking method. It were called gastronomy. Based on that, this paper would be explore about gastronomy of lemang in Lahat. Lemang had a variety of mentions include lomang, malomang, mangalomang, lamang, melemang, malemang and lemang. Each areas called lemang with different mentions. Lomang, malomang, mangalomang were mention for Batak, lamang was mention for Minangkabau, melemang was mention for Bengkulu and lemang was mention for Lahat. In Batak, lemang was so popular because based on history, for the first time lemang come from Batak. Lemang mostly produced by people who lived near the forest, like Tanjung sirih village in Lahat because a type of bamboo was used to produce lemang was special. Lemang was produced by combine gelatinous rice and coconut milk in bamboo, then grilled over the embers during 1 hour.
\end{abstract}

Keywords: Gastronomy, Lahat, Lemang

\section{INTRODUCTION}

Lahat is one of district in South Sumatra where is located $276 \mathrm{Km}$ from Palembang city. Lahat was symboled by Jempol mountain because it has a thumb shaped hill at left side of the road. Geographically, Lahat is located at $3,5^{\circ}$ to $4,5^{\circ}$ south latitude and $103^{\circ}$ to $103,8^{\circ}$ east longitude which is plateau and surrounded by hills and mountains. The hills and mountains are a part of row hill that stretches along Sumatra Island. Based on the Central Bureau Statistic (2021) [3], Lahat has 40 natural tourisms potential, has 22 archaeological tourisms potential, art and culture traditional.

The natural tourisms, archaeological, art and culture tourism was had by Lahat can be seen at Megalit, Lematang river, Serelo hill, some of water fall until the culinary. Each the traditional culinary of
Lahat is fusion between natural, archaeological, art and culture so it has a beauty history. Some of traditional culinary are tempoyak, lempok, gula durian, bubuw and lemang. Lemang is a traditional culinary that available in a long time, not like tempoyak, lempok, gula durian and bubuw. Lemang can found in a long of road side Tanjung sirih - Pulau pinang Lahat, and it are made as souvenirs by tourists.

Lemang has its own history in Lahat. The collaboration of natural, archaeological, art and culture in Lemang, it was called gastronomy. Ardy (2020) [1] said that gastronomy is study that the role of local culture was involved to the culinary. Gastronomy does not miss from history, tradition, technology, nutrition,philosophy, cooking method and politic, so gastronomy can make culture and history was contained in traditional culinary as 
identity area (Ketaren, 2017) [6]. Based on that, this paper the will discuss more deeply gastronomy of lemang. By this paper, it was expected can maintain and increase knowledge about traditional food to milenial generation so that not forget to the historical, cultural, and customs in own area, cooking method so legacy of culinary cultural can be maintained to the next generation. Eating Lemang as typical food from Lahat is also an exciting experience for tourists. In line with research conducted by Karo, increasing tourist visits through experiential marketing is a strategy that has a significant impact on increasing tourist visits to a restaurant or an area or tourist attraction (Karo Karo, 2020)[7].

\section{LITERATURES}

\subsection{Gastronomy}

Gastronomy comes from Ancient greak "gastros" that mean stomach and "nomos" that mean law or rule (Nurzaman dan Widiastuti, 2019) [14]. According Kamus Besar Bahasa Indonesia (KBBI), gastronomy has a mean seni menyiapkan hidangan yang lezat lezat atau tata boga. Nugroho and Hardani (2020) [12] also said that gastronomy is guidance about all of food and drinks. The therms of gastronomy was born from the tilte of poetry in Prancis at 1801 . Gastronomy has a role as a basis to know how are food and drinks was used to build a similiarities and differeces food and drink culture from any countries.

Ketaren (2017) [6] said that the gastronomy has five aspects or viewpoints such as practical gastronomy, teorities, technic, moleculer and food. (1) Practical gastronomy is a gastronomy that has relate between practice and study about preparation, production and serving of food and drinks from any countries in the world. Gastronomy practice concerning at the standar and specific technic process from cultural point of view, national and regional. (2) Teorities gastronomy is a gastronomy that support gastronomy practical by studying process approach, system, recipe, cooking books and etc. the gastronomy teorities can be showed by ability someone to combine food and drinks haved. (3) Technical gastronomy is a gastronomy that review evaluation systemic from anything in gastronomy which need assessment and measurement. This gastronomy be connection between micro food industry that is being scaled up. The subject of this gastronomy are tecnichian, food scientist, spesialisation of people which have a job in food and chef. (4) Molecular gastronomy is a gastronomy in the form of scientific study who studies fisicochemical from raw material during cooking process and sensory phenomenon was feeled. The gastronomy has characteristic by scientific method in observation, hypothesis, experiment. (5) Food gastronomy is a gastronomy that has correlated between food and drinks, include that process to increase delicacy of food.

Based on five aspect of gastronomy (Ketaren, 2017)[6] said include four elements such as historical, cultural, landscape of geography and cooking method. (1) Historical, gastronomy in historical explain about the origin of raw material, how and where some of food are be cultured. (2) Cultural, it is a factor which influences culture of area which consumed that food. (3) Lanscape geography, it is about environment factor (nature and etnic that influences people to cook some of food). Cooking method explain about cooking process generaly, not about technic how to cook because a gastronom should not can be cooking.

\subsection{Lemang}

Lemang is malay culinary expecially Sumatra, Kalimantan and Sulawesi. Malay society make Lemang be traditional food who made when fasting month, eid al-fitr, wedding, and etc. Lemang is culinary which the production was packed by a leave put into bamboo. Lemang was made from glutinous rice is mixed with coconut milk, salt and sugar. Lemang was grilled on the coal during a few hours [6]. The process production lemang can be seen Figure 1 as a pra observation data.

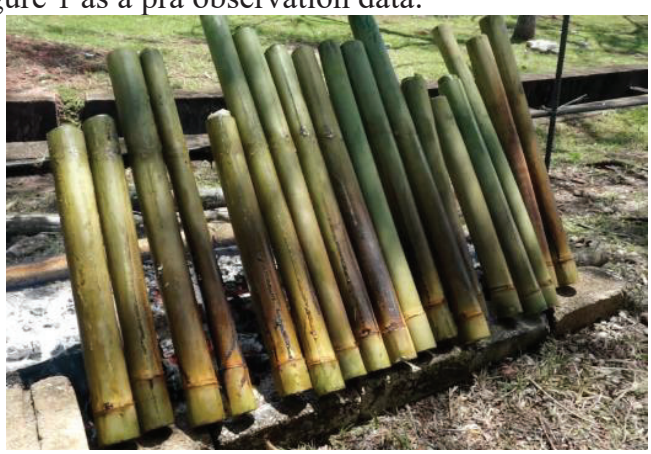

Figure 1. Process production of Lemang

Lemang has characteristic intermediate moisture food with water content 10-40 persen, water activity 0,65-0,90. It makes microbial growth. Lemang contain carbohydrat, fat, protein and other component which can make deterioration for the Lemang. The 
increasing shelf life of food by intermediate moisture food can be conducted by adding preservative and manipulation process. Solichah, et al (2020) [4] said that Lemang production method can affect to the shelf life because cooking method of lemang can affect to the water activity. The principal of cooking method by boiling, steam and grilled have a same principe. They weaken structure of gelatinous rice and make it be ripe. The difference of cooking method of lemang can affect to that characteristic and shelf life.

\section{METHODOLOGY}

The method was used in this research are descriptive with qualitative data approach. Mukthar (2013)[9] said descriptive qualitative is a method that used researcher to found knowledge or theory to research at one specific time. The data was used in this research such as primer and secunder data. The primary data was collected by observation and interview a few producer of lemang. The secondary data was collected by document supporting like journal, E-book and others.

Data and information collection technique such as observation as a technique to collect data that direct observation to the object. Hasan (2002) [8] said that observation are choosing, changing, noting, recording and coding set of behaviors and organization atmosphere. The observation in this research was conducted by observe amount of lemang producer and how to produce lemang.

On the other hand, interview is a technique of collect data by giving question by interviewer to responden, the responden answer was noted and recorded. Indepth interview in this paper was conducted by ask about question historical, cultural, landscape geographical, how to produce lemang.

Walpole (1995) [5] said literature study was conducted to get knowledge to any concept which is used as basic or guidance in research process. The literature study in this paper was needed to explore gastronomi of lemang.

Data and information was used and collect are by sampel. That sampel are a part of population. Collecting sampel are needed to easy researcher to get conclusion. The prosedur of collecting sampel effect refraction in get conclusion, in this research to determine interview informan use snowball sampling.

\section{RESULT AND ANALYSIS}

Based on research, the gastronomy of lemang include historical, cultural, lanscape geography and coking method.

\subsection{The Historical of Lemang}

Lemang was a cooking method to cook rice in bamboo. The description of lemang method come from Ida Pfeiffer. Ida Pfeiffer was a Austrian born girl who had strong desire to travel. Ida Pfeiffer started her journey from Serawak, to Dayak and then Pontianak. After that, Ida Pfeiffer direct her Journey to the Java and Batak in Sumatra.

At 5 August 1852, Ida Pfeiffer arrived in Padang Sidempoean (onderfadeeling Ankola). In Padang Sidempoean, Ida Pfeiffer had a plan journey to the Toba lake. For the journey, Ida Pfeiffer was guided by Dja Pangkat. They started their journey to Silindoeng by pass Sipirok area. From Boeloemario, they through the jungle at as along Batang Toroe, she went to the hill and deep canyon on foot.

In the journey between Sipirok and Silindoeng, they took a rest. Ida Pfeiffer watched how Dja Pangkat and their team prepared a dinner and food to the next day. When they have found the Toba lake, Ida Pfeiffer finished her journey and back to the Padang Sidempoean at august $25^{\text {th }}$. After she took a journey in Batak. Ida Pfeiffer did journey to the Minangkabau (West Sumatra) like Paijakoemboeh, and back to the Batavia. Lemang was cooking method in bamboo, it was called in Minangkabaoe at 1873. The habit of cooked lemang come to Bengkulu at 1900 .

The histocial lemang at Tanjung sirih was come from traditional ceremony of Basemah ethnic like wedding, 14 malam ceremony, fasting month, eid alfitr and etc. in ancient times, lemang was cooked collectively in a large numbers. It was 100 bamboo at once cooked.

Besemah (KBBI: Basemah) or Pasemah is an ethinc group that in habits the area of Pagaralam city, Empat lawang, Ogan komering ulu, Muara enim, and Lahat. Puyang Basemah was called Atung Bungsu. Atung Bungsu had a sister, her name was Puyang Diwe Gumay. Puyang Diwe Gumay had descent, it was called Gumay tribe. Diwe Gumay lived a large area of village. The tribe of Gumay developed be three tribes such as Gumay lembak, Gumay ulu and 
Gumay talang. Gumay lembak and Gumay ulu lived at kecamatan Pulau pinang, while Gumay talang lived at Lahat city.

Gumay lembak tribe, Puyang Muke Akhahan was called Kerie sindang matahari had 8 children. They were Atungkal diwe, Gune raja, Puyang abawan, Puyang bigih, Puyang pandan, Puyang bile raje, Puyang bile bujang, Puyang bile pantas. Of eight Puyang Muke Akhahan children, Puyang abawan lived in Tanjung sirih.

For the first time in Tanjung sirih, lemang was cooked in bamboo Dabuk (Gigantochla pseudoarundinaceae). It has a large size 7-14.5 m from ground level, the surface of bamboo was coated by wax, the diameter was $2-4 \mathrm{~cm}$, and thickness was 3-9 mm. it had green color for the skin [11]. The thickness of Dabuk bamboo made lemang had a long for cooking time, it was 3-4 hours.

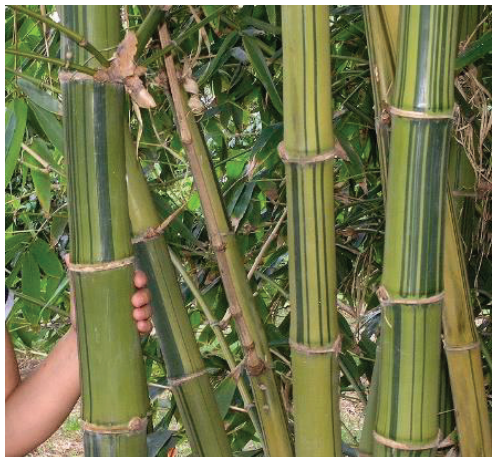

Figure 2 Bamboo Dabuk (Gigantochla pseudoarundinaceae)

Over time, lemang was not only needed to traditional ceremony but also it was be habit each fasting month, eid al-fitr, welcome guest. And now, lemang be souvenir of lahat. As commercial for the first time, lemang was produced and sold by one people at 2000. The producer and seller of lemang increased be more until now. Taking a long time to cooked lemang, bamboo Dabuk hard to got, and demand of lemang increase, it made lemang was cooked by bamboo kapal. Bamboo kapal more easier to get and had skin was thinner.

\subsection{The Cultural of Lemang}

The lemang culture of Lahat has a similar lemang culture of Bengkulu, like language, function and etc. Lemang was a culinary which cooked a rice in bamboo. Each area had own name to called lemang. Batak/ East Sumatra called it "lomang, malomang, mangalomang", Minangkabau /West Sumatra called it "lamang", Bengkulu called it "melemang", Banyuasin in South Sumatra called "malemang", Melayu and Lahat called it "lemang". In Lahat, lemang was be culinary custom. Lemang should be available in wedding ceremony Basemah ethnic. It was requirement and validity of wedding ceremony. A wedding ceremony would be cancel if a groom did not bring a lemang to his bride, and so did she. Lemang was not be culinary, but also it was be folk culture Lahat society. Beside of wedding ceremony, lemang should be available the anniversary of the great day of Islam, fasting month and eid al-fitr, welcome guests and others.

\subsubsection{Lemang in wedding ceremony}

Lemang in wedding ceremony Basemah ethnic was called perkulean lemang. Lemang who brought by groom was lemang gemuk. Lemang gemuk was symboled the color of bamboo had white color, that skin of bamboo have peeled. The names of lemang was adapted to context ceremony like lemang pengantin, lemang pelayan, lemang betuntut dan lainnya. Lemang pengantin was lemang for wedding ceremony. Lemang pelayan was given to leader society like village head.

The responsible party for lemang tradition was a people who had ceremony. To make lemang, not only ivolves groom, bride, family, but also friends, neighbours, and village head. Friends and neighbours can help to looked for spices, cooked, and served lemang to the ceremony. When the deliberation wedding, how much lemang would be calculate and prepared.

The series of Basemah ethnic wedding ceremony between groom and bride should followed their customs. The groom should bring lemang and give some of lemang to the bride. In basemah ethnic, there was 3 steps should have lemang. such as (1) When discussed between both side to set days or wedding time. The groom side should bring 10 bamboo of lemang; (2) when the family of groom delivered groom to bride house, they should bring 65 bamboo of lemang; and (3) when wedding party, they should bring 50 bamboof of lemang.

Lemang gemuk was called lemang who brought by groom, and lemak manis was called for lemang that brought by bride. Lemang gemuk and lemak manis had own philosophy that illustrated mindset the old Basemah people. Lemak manis was symboled a girl, and lemang gemuk was symboled a boy. Lemak manis likened as women clothing, and lemang gemuk 
was symboled as man instrument. The encounter between lemang gemuk dan lemak manis was a reflection a girl and a boy to marriage bond. Lemang from groom side by bride was a tool of information for the family to come in their wedding party, at next day. Lemang was cut, and a piece of lemang as invitation to come at their party. The people who got lemang should bring a rice box which packed by leave, gulai or main course, cake and other. Lemang was brought by groom side, tied up by banana leave. A number of 10 bamboo for bride's parents, 10 bamboo for brother of bride's parents, 10 bamboo for bride, 10 bamboo for groom, and 10 bamboo for village head.

\subsubsection{Lemang in Ramadhan and Eid al-fitr}

When fasting month, each people in Lahat usually cooked lemang and gived it to the mosque. They served lemang as food for iftar that was ate together. When eid al-fitr, they cooked lemang and served it to the guest at halal bi halal.

\subsubsection{Lemang in welcome guest}

Lemang was a traditional food in Lahat. At the big ceremony, lemang usually was given to the guest as symboled of the culture and souvenirs.

\subsection{The Lanscape Geography of Lemang}

Lemang was easy to founded in Lahat, lemang many produced and sold by that residents area at Tanjung sirih village, Pulau pinang. There were two kinds of lemang was much produced and sold like lemang gemuk dan lemang pisang. Lemang gemuk had a umami taste, and lemang pisang had sweet taste because it was mixed with banana. Beside that when fruit season arrived, the producer not only produce lemang gemuk and lemang pisang. They also produce lemang durian, lemang ikan huas and ikan sepit. The price of a them only Rp10,000,00.

Lemang was produced by mixed gelatinous rice and coconut milk, then it was insert into bamboo and grilled over coals. The bamboo which used to produce lemang was a special bamboo, the specific bamboo name was bamboo kapal or Gigantochloa scortechinii Gamble. This bamboo had a larger diameter, and the skin was thinner than other. This bamboo easily porous. The amount of lemang producer was affected by availability of lemang raw material. In Tanjung sirih, bamboo kapal was easy to got. This bamboo was available in forest, the producer lemang in Tanjung sirih got lemang from Tanjung sirih and Gumay ulu.

\subsection{The Cooking Method of Lemang}

Lemang was made from gelatinous rice, coconut, salt and sugar. The composition of lemang such as $1 \mathrm{~kg}$ gelatinous rice, $1 \mathrm{~L}$ coconut milk, 1 tespoon salt, a sheet banana leave, bamboo kapal with size $30 \mathrm{~cm}$. Here's how to make lemang, such as (1) gelatinous rice was washed and soaked during one hour; (2) after one hour soeaked, it was drained; (3) combine gelatinous rice and coconut milk, added salt and sugar.

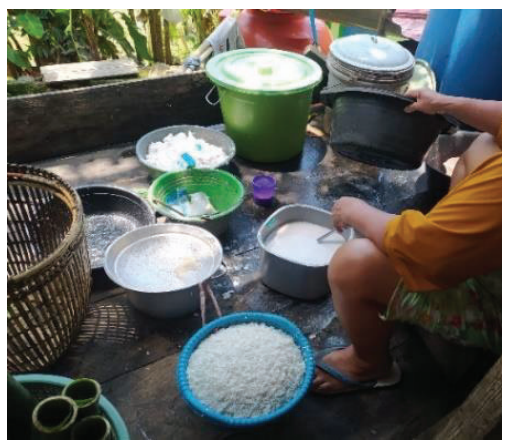

Figure 3. Prepared cook lemang

a. Bamboo that has been cleaned, the inside of bamboo was coated by banana leave

b. The mixture of gelatinous rice and coconut milk insert into bamboo as $3 / 4$ part of bamboo

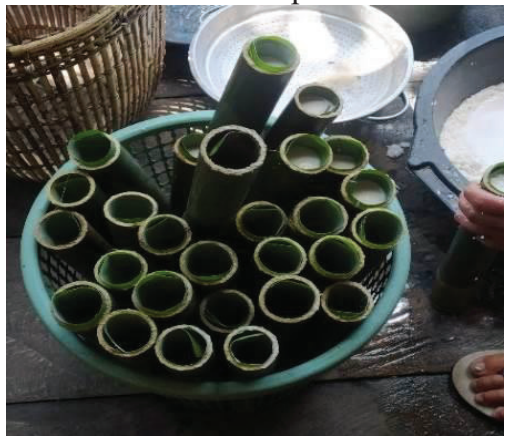

Figure 4. Banana leave in bamboo

c. Put bamboo over the embers during 1 hour

d. Once mature, lemang was ready to was ate 


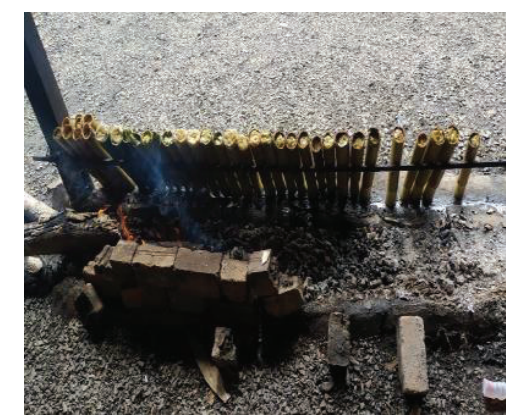

Figure 5. Lemang was grilled

\section{CONCLUSION}

The gastronomy of lemang include 4 elements, such as historical, cultural, landscape geography and cooking method. The historical of lemang was started from Batak to Minangkabau, Bengkulu, Pagaralam and Lahat, lemang was used in wedding ceremony, fasting month and eid al-fitr, welcome guset. Lemang was produced in a producer who live near a forest like Tanjung sirih village. The main material to produced lemang like bamboo available in Tanjung sirih and Gumay ulu. Lemang was produced by combine gelatinous rice and coconut milk in bamboo kapal, then grilled it over the embers during 1 hour.

\section{AUTHORS' CONTRIBUTIONS}

Sonjaya, A.M., Pratama, M., and Rahmania, T. contributed to the design, analysis, and writing the manuscript.

\section{ACKNOWLEDGMENTS}

The gratitude and sincere appreciation to all parties who have assisted in the data collection process, especially the tourism office of the Lahat district and lemang SMEs in Lahat, as well as reviewers who have contributed their expertise and time to review the manuscripts, to evaluate and to assess the articles submitted for consideration in the publication process.

\section{REFERENCES}

[1] Ardy, N. Yulihasri. 2020. Strategi pengembangan atraksi pengolahan rendang (marandang) sebagai daya tarik wisata gastronomi di kampung rendang kota Payakumbuh, in :Journal Economy, pp : 134154. DOI :https://doi.org/ 10.47896/je. v23i2.216
[2] BA. Wahyudi, FA. Octavia, M Hadipraja, S Isnaeniah, V Viriani, Lemang ( Rice bamboo ) as a representative of typical Malay food in Indonesia, in : Journal of ethnic food, 2017, pp : 3-7. DOI : https://doi.org/10.1016/j.jef.2017. 02.006

[3] Badan Pusat Statistik, in : Pariwisata kabupaten lahat booklet, DOI : pdf (bps.go.id)

[4] E. Solichah, R. Kumalasari, N. Afifah, N. Indrianti, FN. Firdaus, A. Rahayuningtyas, T. Budiati, Pengaruh proses pemasakan dan penambahan bahan pengawet terhadap karakteristik lemang selama masa penyimpanan, in : Journal PANGAN, 2020, pp $149-160 . \quad$ DOI: https://doi.org/10.33964/jp.v29i2

[5] E. Walpole, Pengantar Statistika, in: Erlangga, Jakarta, 1995

[6] I. Ketaren, Gastronomi upaboga Indonesia, in : IGA Press, Jakarta, 2017

[7] Karo Karo, P. (2020). Analysis of Experiential Marketing Effect on Tourist Satisfaction Levels at The Tourist Restaurant in Belitung District. Tourism Scientific Journal, 5(2). https://doi.org/10.32659/tsj.v5i2.79

[8] MI. Hasan, Pokok-pokok materi metodologi penelitian dan aplikasiny, in : Ghalia Indonesia, Bogor, 2002

[9] Mukhtar, Metode praktis penelitian dekriptif kualitatif, in: Referensi, Jakarta, 2013

[10] NFN Refisrul, Fungsi lemang dalam upacara perkawinan suku Basemah di kabupaten Kaur provinsi Bengkulu, in : Jurnal penelitian sejarah dan budaya, pp: 235-256. DOI : https://doi.org/10.36424/jpsb.v5i2.141

[11] RW. Hastuti, AP. Yani, I. Ansori, Studi keanekaragaman jenis bambu di desa tanjung terdana Bengkulu tengah, in : Journal Pendidikan dan Pembelajaran Biologi, pp: 96102, 2018. DOI : https://doi.org/10.33369/diklabio.2.1.96-102

[12] SP.Nugroho, IP Hardani, Gastronomi makanan khas keraton yogyakarta sebagai upaya pengembangan wisata kuliner, in : Journal Pariwisata, 2020, pp : 52-62. DOI : https://doi.org/10.31294/par.v7i1.8136 
[13] Tropical Looking Plants. Gigantochloa maxima bamboo, in : The international palm society,

2012,https://www.palmtalk.org/forum/index.ph $\mathrm{p} \quad$ ?/topic/33837-gigantochloa-maximabamboo/

[14] Y. Nurzaman, N. Widiastuti, Meningkatkan kemampuan wirausaha melalui pelatihan life skill tata boga bagi warga belajar keaksaraan (studi kasus di PKBM Srikandi kota Cimahi), in : Community education journal, 2019, pp: 202-209. DOI

http://dx.doi.org/10.22460/commedu.v2i3.2885 